\title{
Faktor yang Mempengaruhi Penderita TB Paru Terhadap Kepatuhan Minum Obat Anti Tuberkulosis di Puskesmas Jatisawit Indramayu
}

\author{
Factors The Affecting of Pulmonary Tuberculosis Patient to Drinking Anti-Tuberculosis Drug \\ Adherence In Puskesmas Jatisawit Indramayu
}

\section{Rusman, Sarinah Basri K}

\section{Program Studi Kesehatan Masyarakat Universitas Wiralodra}

email : $\underline{\text { usman2019@yahoo.com, b_sarinah@yahoo.com }}$

\begin{abstract}
Abstrak
Penyakit Tuberkulosis Paru dari tahun ke tahun meningkat dan sebagian masih perlu pengobatan lanjutan artinya tingkat kesembuhan belum mencapai $100 \%$. Penyakit ini dapat disembuhkan kalau penderita teratur dan patuh minum Obat Anti Tuberkulosis (OAT).

Peneltian ini bertujuan untuk mengetahui fakto pendidikan, faktor pengetahuan dan faktor sikap pada penderita TB paru terhadap kepatuhan minum Obat Anti Tuberculosis (OAT) pada pasien TB paru di Puskesmas Jatisawit indramayu.

Sampel terdiri dari 43 orang dengan metode total sampling. Jenis penelitian ini adalah deskriptif analitik dengan pendekatan cross sectional. Analisis data yang digunakan adalah analisis unvariat dan analisis bivariat dengan uji chisquare.

Hasil penelitian ini menunjukan maka dapat dilihat hubungan sabagai berikut (1) Tidak ada hubungan antara pendidikan dengan kepatuhan minum OAT ( $p$-Value 0,082, $p>0,05$ ); (2) Ada hubungan antara pengetahuan dengan kepatuhan minum OAT ( $p$-Value $0,012, p<0,05$ ) dan (3) ada hubungan antara sikap dengan kepatuhan minum OAT ( $p$-Value 0,040, $p<0,05$ ). Perlu dilakukan penyuluhan, monitoring dan evaluasi secara rutin dan berkala; meningkatkan kerjasama dan kemitraan dengan instsnsi pemerintah dan swasta yang memiliki konsen tehadap penyakit TB paru serta memberi motivasi terhadap penderita TB paru.
\end{abstract}

Kata kunci: Pendidikan, Pengetahuan, Sikap, Kepatuhan minum OAT

\section{Abstract}

Pulmonary tuberculosis from year to year increases and some still need further treatment, meaning that the cure rate has not reached $100 \%$. This disease can be cured if the patient is regular and obedient in taking Anti Tuberculosis (OAT) medicine.

This study aims to determine the fact of education, knowledge factors and attitudinal factors in pulmonary TB patients against adherence to taking anti-tuberculosis drugs (OAT) in pulmonary TB patients at the Jatisawit indramayu health center.

The sample consisted of 43 people with a total sampling method. This type of research is descriptive analytic with cross sectional approach. Analysis of the data used is unvariat analysis and bivariate analysis using chi-square test.

The results of this study indicate that the relationship can be seen as follows (1) There is no relationship between education and compliance with drinking OAT ( $p$-Value 0.082, p>0.05); (2) There is a relationship between knowledge and compliance with OAT ( $p$-Value 0.012, $p<0.05)$ and (3) there is a relationship between attitudes and compliance with OAT ( $p$ Value 0.040, $p<0.05$ ).

Extension, monitoring and evaluation needs to be done regularly and periodically; enhance cooperation and partnerships with government and private institutions that have concerns about pulmonary TB disease and provide motivation for pulmonary TB sufferers.

Keyword : Education, Knowledge, Attitude, Compliance with OAT

\section{Pendahuluan}

TB atau Tuberkulosis adalah suatu penyakit infeksi yang disebabkan oleh bakteri micro tuberculosis yang dapat menular melalui percikan dahak. Tuberkulosis bukan penyakit keturunan atau kutukan dan dapat disembuhkan dengan pengobatan teratur, diawasi oleh Pengawasan Minum Obat (PMO). Tuberkulosis adalah penyakit menular langsung yang disebabkan oleh kuman TB. Sebagian besar kuman TB menyerang paru tetapi bisa juga organ tubuh lainnya. ${ }^{1}$

Menurut Global Tuberculosis Report WHO (2016), diperkirakan insidens tuberculosis di Indonesia pada tahun 2015 sebesar 395 kasus/100.000 penduduk dan angka kematian sebesar 40/100.000 penduduk (penderita HIV dengan tuberkulosis tidak dihitung) dan 10/100.000 penduduk pada penderita HIV 
dengan tuberkulosis. Menurut perhitungan model prediction yang berdasarkan data hasil survei prevalensi tuberkulosis tahun 20132014, estimasi prevalensi tuberkulosis tahun 2015 sebesar 643 per 100.000 penduduk dan estimasi prevalensi tuberkulosis tahun 2016

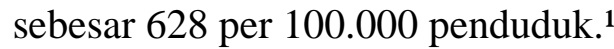

Pada tahun 2016 ditemukan kasus suspek TB Paru yaitu Orang yang memiliki gejala utama batuk berdahak selama 2-3 minggu atau lebih. Batuk dapat diikuti dengan gejala tambahan yaitu dahak bercampur darah, batuk berdarah, sesak nafas, badan lemas, nafsu makan menurun, berat badan menurun, malaise, berkeringat malam hari tanpa kegiatan fisik, demam meriang lebih dari satu bulan sebanyak 259.933 kasus dari hasil pemeriksaan Lab hanya ditemukan kasus baru indikasi BTA + sebanyak 34.070 orang, atau 13,11\% dari suspec TB Paru angka ini masih dalam batas toleransi antara $5-15 \%$, jika angka ini $<5 \%$ itu menunjukkan penjaringan suspec terlalu longgar atau ada masalah dalam pemeriksaan lab (negatif palsu) dan sebaliknya jika > $15 \%$ menunjukkan penjaringan terlalu ketat atau ada masalah dalam pemeriksaan lab (positif palsu), Jumlah keseluruhan kasus TB Paru pada tahun 2016 sebanyak 57.247 kasus dan kasus pada anak sebanyak 6.600 orang $(11,53 \%){ }^{1}$

Indonesia merupakan negara pertama diantara High Burden Country (HBC) di wilayah WHO South-East Asian yang mampu mencapai target global TB untuk deteksi kasus dan keberhasilan pengobatan pada tahun 2006. Pada tahun 2009, tercatat sejumlah 294.732 kasus TB telah ditemukan dan diobati (data awal Mei 2010) dan lebih dari 169.213 diantaranya terdeteksi BTA+. Dengan demikian, Case Notification Rate untuk TB BTA+ adalah 73 per 100.000 (Case Detection Rate $73 \%$ ). Rerata pencapaian angka keberhasilan pengobatan selama 4 tahun terakhir adalah sekitar $90 \%$ dan pada kohort tahun 2008 mencapai 91\%. Pencapaian target global tersebut merupakan tonggak pencapaian program pengendalian $\mathrm{TB}$ nasional yang utama. $^{1}$

Pada tahun 2015 diperkirakan terdapat 10,4 juta kasus baru tuberkulosis atau 142 kasus/100.000 populasi, dengan 480.000 kasus multidrug-resistant. Indonesia merupakan negara dengan jumlah kasus baru terbanyak kedua di dunia setelah India. Sebesar 60\% kasus baru terjadi di 6 negara yaitu India, Indonesia, China, Nigeria, Pakistan dan Afrika Selatan. Kematian akibat tuberkulosis diperkirakan sebanyak 1,4 juta kematian ditambah 0,4 juta kematian akibat tuberkulosis menurun 22\% antara tahun 2000 dan 2015, tuberkulosis tetap menjadi 10 penyebab kematian tertinggi di dunia pada tahun 2015 . $^{2}$

Di Indonesia Tuberkulosis Paru merupakan masalah utama kesehatan masyarakat. Jumlah penderita Tuberkulosis Paru di Indonesia merupakan ke-3 terbanyak di dunia setelah India dan Cina dengan jumlah penderita sekitar $10 \%$ dari total jumlah penderita Tuberkulosis Paru di Dunia. Diperkirakan pada tahun 2004, setiap tahun ada 539.000 kasus baru dan kematian 101.000 orang. Insidensi kasus Tuberkulosis Paru BTA positif sekitar 110 per 100.0000 penduduk. $^{2}$

Dibandingkan dengan Provinsi lainnya di Indonesia, Jawa Barat menduduki rangking pertama jumlah terbesar penderita TB. Untuk itu, Pemerintah Provinsi Jawa Barat, tahun 2015 menargetkan dapat menanggulangi penyakit $\mathrm{TB}$ dan menempatkan penyakit tersebut sebagai program unggulan Dinas Kesehatan Jawa Barat. Data di Dinas Kesehatan Jawa Barat, CNR tahun 2010 tercatat 76,22/100.000 penduduk. Trend CNR di Provinsi Jawa Barat periode tahun 2010 - 2015 cenderung naik, dari 76,22/100.000 pada tahun 2010 menjadi $138,87 / 100.000$ pada tahun 2015, dan pada tahun 2016 mengalami penurunan cukup signifikan pada posisi $120,25 / 100.000 .^{3}$

Tindakan pencegahan yang dapat dilakukan dengan mengobati penderita Tuberkulosis Paru secara rutin sesuai jadwal pengobatan, bila dirawat di rumah penderita harus ditempatkan 
pada ruangan dengan segala peralatan tersendiri dan lantai dibersihkan dengan desinfektan yang cukup kuat. Selain itu diperlukan upaya untuk perbaikan status gizi pada penderita dan waktu istirahat yang cukup. Peningkatan daya tahan tubuh penderita harus dijaga karena mereka rentan terhadap penyakit. Sulitnya pemberantasan penyakit ini karena dalam pemberantasannya bukan hanya masalah bakteri atau obat-obatan saja, melainkan melengkapi aspek sosial, budaya, ekonomi, tingkat pendidikan, pengetahuan penderita dan keluarga, serta lingkungan masyarakat sekitar. ${ }^{4}$

Berdasarkan hasil peneitian yang dilakukan oleh Friska Junita, (2012) hasil uji statistic hubungan pengetahuan dengan kepatuhan diperoleh nilai $\mathrm{P}=0,0005$ lebih kecil dari nilai alpa $=0,05$ maka dapat di simpulkan bahwa $\mathrm{H} 0$ ditolak, artinya ada hubungan yang angat signifikan antara pengetahuan dengan kepatuhan meminum obat anti tuberculosis, dan berdasarkan hasil uji statistik hubungan sikap dengan kepatuhan diperoleh nilai $\mathrm{P}=0,0005$ lebih kecil dari nilai alpa $=0,05$ maka dapat di simpulkan bahwa H0 ditolak dan Ha gagal ditolak, ada hubungan yang sangat signifikan antara sikap dengan kepatuhan meminum obat anti tuberkulosis pada pasien tuberkulosis paru. $^{5}$

Untuk mengatasi masalah tersebut, peran serta keluarga sangat dibutuhkan, dimana keluarga sebagai unit pertama dalam masyarakat. Apabila salah satu anggota keluarga terkena penyakit Tuberkulosis Paru akan berpengaruh terhadap anggota keluarga yang lain. Untuk mewujudkan keluarga yang sehat terhindar dari resiko penularan, maka harus ditunjang dengan pengetahuan tentang Tuberkulosis Paru. Pengetahuan yang baik akan mempengaruhi tindakan keluarga untuk bertindak dalam hal pencegahan penularan dan proses kesembuhan penderita. Sebaliknya makin rendah pengetahuan keluarga tentang bahaya penyakit Tuberkulosis Paru, makin besar pula resiko terjadi penularan dan proses kesembuhan penderita kurang optimal. Jumlah penduduk di Kabupaten Indramayu 2016, sebanyak 1.728.050 jiwa. Jumlah keseluruhan penderita BTA positif Kabupaten Indramayu 2017 sebanyak 816 penderita dan kasus TB MDR sebanyak 25 orang. ${ }^{6}$

Di Puskesmas Jatisawit selama tahun 2014 terdapat kasus Tuberkulosis Paru sebanyak 27 kasus, sedangkan Tuberkulosis Paru dengan BTA positif sebanyak 18 orang, dan semuanya diberi Obat Anti Tuberkulosis (OAT). Tahun 2015 suspek yang diperiksa sputum 148 orang dan yang dinyatakan penderita + Tuberkulosis Paru sebanyak 20 penderita dan semuanya diobati Obat Anti Tuberkulosis (OAT), sampai akhir tahun 2015, 10 penderita dinyatakan sembuh dengan pemeriksaan BTA-, sedang sisanya masih dalam pengobatan. Tahun 2016 terdapat kasus Tuberkulosis Paru sebanyak 40 kasus, sedangkan Tuberkulosis Paru dengan BTA positif sebanyak 25 orang, dan semuanya diberi Obat Anti Tuberkulosis (OAT), DO 1 orang dan meninggal 1 orang. Tahun 2017 terdapat kasus Tuberkulosis Paru sebanyak 43 kasus, sedangkan Tuberkulosis Paru dengan BTA positif sebanyak 25 orang dan semuanya diberi Obat Anti Tuberkulosis (OAT), DO 1 orang dan meninggal 3 orang. ${ }^{6}$

Dari gambaran di atas dapat dilihat bahwa penyakit Tuberkulosis Paru dari tahun ke tahun meningkat dan sebagian masih perlu pengobatan lanjutan artinya tingkat kesembuhan belum mencapai 100\%. Padahal penyakit ini dapat disembuhkan kalau penderita teratur dan patuh minum Obat Anti Tuberkulosis (OAT). Karena pemberantasan dan penanggulangan penyakit ini merupakan program nasional maka segala sesuatu mengenai keberhasilan dari pengobatan penderita Tuberkulosis Paru mendapatkan dukungan dari pemerintah secara utuh. Salah satunya melalui Puskesmas yaitu berupa pemberian secara gratis, susu, beras dan makanan-makanan suplemen untuk menaikkan kasus gizi penderita. $^{7}$

Berdasarkan gambaran di atas maka peneliti tertarik untuk melakukan penelitian mengenai 
faktor yang mempengaruhi penderita TB Paru terhadap kepatuhan minum Obat Anti Tuberkulosis (OAT) di Puskesmas Jatisawit Indramayu tahun 2018.

\section{Metode Penelitian}

Jenis penelitian ini adalah penelitian analitik observasional, berdasarkan waktu pelaksanaannya penelitian ini bersifat cross sectional. Penelitian ini menggunakan toal smpling dalam penentuan sampelnyan, dengan sampel 43 orang responden yang diambil dari seluruh populasi. Adapun lokasi dan waktu penelitian ini dilaksanakan di Puskesmas Jatisawit Indramayu pada bulan Agustus 2018. Variabel yang diteliti, sebagai variabe independen pendidikan, pengetahuan dan sikap serta sebagai variabel dependen kepatuhan minum OAT maka, digunakan analisis univariat untuk mengetahui distribusi frekuensi masing-masing variabel dan analisis bivariat dengan uji chi-square untuk mengetahui hubungan masing-masing variabel independen terhadap variabel dependennya.

\section{Hasil}

\section{Analisis Univariat}

Tabel 1. Tabulasi Silang Variabel Bebas dan Variabel Terikat

\begin{tabular}{lllclc}
\hline \multirow{2}{*}{ Variabel } & \multirow{2}{*}{ Kategori } & \multicolumn{3}{c}{ Variabel Kepatuham Minum OAT } \\
\cline { 3 - 6 } & & \multicolumn{2}{c}{ Tidak Patuh } & \multicolumn{2}{c}{ Patuh } \\
\cline { 3 - 6 } & & F & \% & F & \% \\
\hline \multirow{2}{*}{ Pendidikan } & Pendidikan Rendah & 5 & 31,2 & 11 & 68,8 \\
& Pendidikan Tinggi & 2 & 7,4 & 25 & 92,6 \\
\multirow{2}{*}{ Pengetahuan } & Pengetahuan Cukup & 5 & 41,7 & 7 & 58,3 \\
\multirow{2}{*}{ Sikap } & Pengetahuan Kurang & 2 & 6,5 & 29 & 93,5 \\
& Sikap Mendukung & 4 & 40,0 & 6 & 60,0 \\
& Sikap Tidak Mendukung & 3 & 9,1 & 30 & 90,9 \\
\hline
\end{tabular}

Berdasarkan tabel 1, dapat diamati dari 43 orang responden yang mengalami TB sebanyak 27 orang $(62,8 \%)$ memiliki pendidikan yang relatif tinggi sedangkan yang berpendidikan rendah ada 16 orang $(37,2 \%)$. Dari data tersebut dapat disimpulkan bahwa sebagian besar pasien TB di wilayah UPTD Puskesmas Jatisawit tahun 2018 berpendidikan tinggi. Dari 43 orang responden yang mengalami TB sebanyak 31 orang $(72,1 \%)$ memiliki pengetahuan yang relatif baik, sedangkan yang 12 orang $(27,9 \%)$ memiliki pengetahuan yang kurang. Dari data tersebut dapat disimpulkan bahwa sebagian besar pasien TB paru di wilayah UPTD Puskesmas Jatisawit tahun 2018 memiliki pengetahuan yang baik terhadap penyakit TB paru. Dari 43 orang responden yang mengalami TB sebanyak 33 orang $(76,7 \%)$ memiliki sikap yang mendukung keputatuhan minum obat ani TB, sedangkan yang 10 orang $(27,9 \%)$ memiliki sikap tidak mendukung terhadap kepatuhan minum obat anti TB. Dari data tersebut dapat disimpulkan bahwa sebagian besar pasien TB paru di wilayah UPTD Puskesmas Jatisawit tahun 2018 memiliki sikap yang mendukung terhadap kepatuhan minum obat anti TB.

\section{Analisis Bivariat}


Tabel 2. Hasil Uji Chi-square

\begin{tabular}{llrll}
\hline \multicolumn{1}{c}{ Variabel Bebas } & Variabel Terikat & $\boldsymbol{p}$-value & Uji Statistik & \multicolumn{1}{c}{ Keterangan } \\
\hline Pendidikan & & 0,082 & Chi-square & Tidak Ada hubungan \\
Pengetahuan & $\begin{array}{l}\text { Kepatuhan } \\
\text { Minum Obat Anti }\end{array}$ & 0,012 & Chi-square & Ada hubungan \\
Sikap & $\begin{array}{l}\text { Tuberculosis } \\
\text { Pund }\end{array}$ & 0,040 & Chi-square & Ada hubungan \\
\hline
\end{tabular}

\section{Pembahasan}

Pendidikan merupakan faktor utama pembentuk perilaku, menurut Lawrance Green yang dikutip Notoatmodjo (2007) pendidikan adalah salah satu faktor predisposisi dalam teori perubahan atau pembentuan perilaku. Patuh minum obat anti tubercolusis (OAT) adalah salah satu perilaku yang dapat diamati dan dinilai baik dengan cara obsrvasi maupun recall. Pada umumnya semakin tinggi pendidikan seseorang maka akan semakin baik perilakunya, begitupun sebaliknya semakin rendah pendidikan maka akan semakin buruk perilakunya. $^{8}$

Menurut Stein 1986, tingkat pendidikan pasien dapat meningkatkan kepatuhan, sepanjang bahwa pendidikan tersebut merupakan pendidikan yang aktif yang diperoleh secara mandiri, lewat tahapan tahapan tertentu. ${ }^{9}$ Berdasarkan tabulasi silang antara pendidikan dengan kepatuhan penderita di Puskesmas Jatisawit 2018 penderita yang rendah cenderung tidak patuh minum OAT. Namun pada penderita yang pendidikan lebih tinggi mempunyai tingkat kepatuhan dan tidak kepatuhan yang seimbang. Berdasarkan analisis statistic Chi-Squeare Test nilai sgnifikan pValue $=0,082, \quad \mathrm{p}$-Value $>0,05$ artinya Ho diterima, jadi tidak ada hubungan antara pendidikan dengan kepatuhan minum OAT di wilayah Puskesmas Jatisawit Indramayu.

Jadi hasil tersebut membuktikan bahwa pendidikan memang bukan menyebabkan perubahan perilaku. Perilaku akan berubah sesuai pendidikanya apabila ia mempunyai motivasi dalam dirinya, dan motivasi itu sendiri akan timbul bila ada kebutuhan yang tidak dapat ditunda pemenuhanya. Pasien TB dengan pendidikan rendah dang tinggi memiliki kesempatan yang sama terhadap kepatuhan untuk minum Obat Anti Tuberkulosis di Puskesmas Jatisawit Indramayu.

Pengetahuan merupakan hasil dari tahu, dan ini terjadi setlah seseorang melakukan penginderaan terhadap suatu objek tertentu. Penginderaan ini terjadi melalui panca indera manusia, yauitu penglihatan, pendengaran, penciuman, rasa dan raba. Sebagin besar pengetahuan diperoleh memalui mata dan telinga. Pengetahuan atau kognitf mrupakan domain yag sangat penting untuk terbentuknya suatu perilaku. ${ }^{9}$

Salah satu penunjang keberhasilan pengobatan TB Paru adalah dengan mengetahui seberapa jauh pengetahuan penderita tentang TB Paru. Pengetahuan penderita mengenai istilah TB Paru, gejala dan penularannya di Puskesmas Jatisawit Indramayu masih tergolong kurang baik. Padahal kemampuan dan pengetahuan masyarakat atau penderita akan gejala penyakit TB Paru dan bagaimana cara penularannya sangat mutlak dipahami. Karena dalam tahap ini, dapat dilakukan pencegahan terjangkitnya penyakit TB Paru. Atau setidaknya penyakit penderita dapat diketahui lebih dini sehingga pengobatan yang 
akan dilakukan tidak terlalu lama dan memiliki resiko kegagalan lebih kecil.

Tingkat memahami penderita berdasarkan hasil penelitian cenderung baik. Penderita memiliki pengetahuan yang kurang akan tetapi penderita memahami sedikit informasi yang mereka dapat dengan baik. Sehingga saat penderita memiliki pemahaman yang baik maka diharapkan aplikasi juga baik. Berdasarkan hasil penelitian diketahui bahwa aplikasi penderita terkait pengetahuan dan memahami yang telah dimiliki kurang baik sehingga bisa dikatak an bahwa penderita sangat kurang dalam mengaplikasikan pengetahuan dan pemahaman yang telah didapat.

Berdasarkan tabulasi uji statitik dengan chisquare antara variabel pendidikan dengan variabel penerapan kepatuhan minum OAT diperoleh $\mathrm{p}=0,012(\mathrm{p}<0,05)$ yang artinya ada hubungan yang signifikan antara pendidikan dengan penerapan kepatuhan minum OAT, serta diperoleh koefisien kontingensi $(\mathrm{CC}=0,403)$ yang artinya ada hubungan cukup kuat antara pengetahuan penderita dengan kepatuhan minum OAT. Berdasarkan kroscek dari register TB 01 dan wawancara langsung kepada responden TB Paru dapat diketahui tentang tata cara minum obat melalui sisa bungkus minum OAT dan rutin atau tidaknya responden meminum OAT.

Sejalan juga dengan penelitian yang dilakukan oleh Gendis Indra Dewi (2011) menunjukan bahwa pengetahuan respoden tentang TB Paru termasuk dalam katagori baik $(75,0 \%) .{ }^{10}$ Hal ini juga sejalan dengan penelitian yang dilakukan oleh Iman Taufik 2015 dengan hasil uji statistic p-Value sebesar 0,001 sehingga lebih kecil dari 0,05. Dengan demikian, ada hubungan yang signifikan antara pengetahuan dengan kepatuhan berobat Penderita TB Paru di UPTD Puskesmas DTP Cidempet Kabupaten Indramayu Tahun 2015. ${ }^{11}$ Hal tersebut mebuat penelitian ini menguatkan teori perubahan atau pembentukan perilaku yang menyatakan bahwa salah satu faktor dari perubahan atau pembentukan dari suatu perilaku adalah pengetahuan.

Sikap dapat dianggap sebagai suatu predisposisi umum untuk berespon atau bertindak faktor yang mempresdiposisi terjadinya perilaku pada diri seseorang atau masyarakat adalah pengetahuan dan sikap seseorang dan masyarakat tersebut terhadap apa yang akan dilakukan. Menurut Notoatmojo (2005) Sikap merupakan reaksi interval seseorang dipengaruhi oleh berbagai factor yaitu pengalaman pribadi, kebudayaan, orang lain yang dianggap penting, agama serta factor emosi dalam diri individu yang memegang peranan penting untuk terbentuknya sikap. ${ }^{9}$

Berdasarkan tabel diatas dapat dilihat bahwa, hasil uji statistic Chi-Squeare Test nilai sgnifikan $\mathrm{p}$-Value $=0,040, \quad \mathrm{p}$-Value $<0,05$ artinya Ho ditolak, jadi ada hubungan antara pengetahua dengan kepatuhan minum OAT di wilayah Puskesmas Jatisawit Indramayu, serta diperoleh koefisien kontingensi $(\mathrm{CC}=0,333)$ yang artinya ada hubungan lemah antara pengetahuan responden dengan kepatuhan minum OAT. Dapat dilihat bahwa sikap responden yang tidak mendukung yaitu sebanyak 23,3\% , sedang respoden yang mendukung yaitu $76,7 \%$. Hasil penelitian ini sesuai dengan penelitian yang dilakukan oleh Zalmi (2008) didapatkan bahwa terdapat hubungan yang bermakna antara sikap responden dengan kepatuhan minum OAT dimana nilai $\mathrm{p}$-value $<0,05 .{ }^{12}$ Pada penelitian Machita Hanum (2011) tentang analisis hubungan perilaku masyarakat dengan lingkungan fisisk terhadap penularan penyakit TB Paru di Jombang, penelitian ini menggunakan disain cross sectional dari hasil penelitiannya didapatkan $\mathrm{p}=0,035$ berarti terdapat hubungan yang bermakna antara sikap dengan kepatuhan. ${ }^{13}$

Dari penelitian diatas terdapat kesamaan yaitu ada hubungan bermakna antara hubungan sikap dengan kepatuhan minum OAT. Sikap merupakan suatu perilaku yang dimiliki 
seseorang sebelum mengambil tindakan. Jika sikap masyarakat sudah baik maka masyarakat akan mudah untuk melakukan suatu perbuatan yang baik, tapi jika sikap ini masih kurang maka memiliki dampak yang buruk bagi derajat kesehatan masyarakat. Untuk merubah sikap pengetahuan harus ditingkatkan dan pemerintah harus memberikan contoh yang baik kepada masyarakat agar perilaku hidup sehat dapat terlaksana.

\section{Kesimpulan}

Penelitian mengenai pengaruh pendidikan, pengetahuan dan sikap penderita TB Paru terhadap kepatuhan minum OAT di Puskesmas Jatisawit tahun 2018, didapat kesimpulan :

1. Sebagian besar responden berpendidikan tinggi, 27 orang $(62,8 \%)$ dan 16 orang $(36,2 \%)$ lainnya masih berpendidkan rendah.

2. Sebagian besar responden memiliki pengetahuan yang baik, 31 Orang $(72,1 \%)$ dan 12 orang $(27,9 \%)$ lainnya masih memiliki pengetahuan yang kurang tentang penyakit TB paru.

3. Sebagian besar responden bersikap mendukung minum OAT, 33 orang $(76,7 \%)$ dan masih terdapat 10 orang $(23,3 \%)$ responden belum bersikap mendukung terhadap minum OAT.

4. Sebagian besar responden memiliki perilaku patuh minum OAT, 36 orang $(83,7 \%)$ dan 7 orang $(16,3 \%)$ laninnya masih tidak patuh untuk minum OAT.

5. Tidak ada hubungan antara pendidikan dengan kepatuhan minum OAT (p-Value $0,082, \mathrm{p}>0,05)$

6. Ada hubungan antara pengetahuan dengan kepatuhan minum OAT (p-Value 0,012, p $<0,05$ )

7. Ada hubungan antara sikap dengan kepatuhan minum OAT (p-Value 0,040, p $<0,05)$.

\section{Saran}

\section{Daftar Pustaka}

1. Kementrian Kesehatan Republik Indonesia Direktorat Jendral Pengendalian Penyakit dan Penyehatan Lingkungan. Pedoman Nasional Pengendalian Tuberkulosis. 2017. Hal $1-5$. 
2. Depkes. R.I. 2008. Pedoman Nasional Penanggulangan Tuberkulosis. Cetakan Kedua.Jakarta : Bakti Husada.

3. Dinas Kesehatan Provinsi Jawa Barat, 2018. Profil Kesehatan Jawa Barat Tahun 2017.

4. Eka, W., 2006. Hubungan Antara Pengetahuan Tentang Penyakit TB Paru dengan Tindakan Pencegahan Penularan Pada Keluarga Penderita TB Paru. Skripsi. Surabaya, Universitas Airlangga.

5. Friska Junita. 2012. Hubungan Pengetahuan dan Sikap Dengan Kepatuhan Minum Obat Anti Tuberculosis pada Pasien Tuberculosis Paru di Puskesmas Kecamatan Jatinegara. KTI. Program Studi D III Kebidanan Sekolah Tinggi Ilmu Kesehatan Medistra Indonesia Bekasi.

6. Dinas Kesehatan Kabupaten Indramayu, 2018. Profil Kesehatan Indramayu Tahun 2017.

7. Puskesmas Jatisawit, 2017. Buku Kunjungan Pasien. Indramayu: Jatisawit.

8. Notoatmodjo, Soekidjo. 2007. Kesehatan Masyarakat Ilmu dan Seni. Jakarta. Rieneka Cipta.

9. Notoatmodjo, Soekidjo. 2005. Promosi Kesehatan Teori dan Aplikasi. Jakarta: Rineka Cipta.

10. Gendhis I.D. 2011. Hubungan Antara Pengetahuan, Sikap Pasien dan Dukungan Keluarga dengan Kepatuhan Minum Obat pada Pasien TB Paru di BKPM Pati. Jurnal Penelitian. Semarang: Prodi S1. Keperawatan STIKES Telogorejo Semarang.

11. Iman Taufik. 2015. Hubungan Pengetahuan dengan kepatuhan berobat Penderita TB Paru di UPTD Puskesmas DTP Cidempet Kabupaten Indramayu.
12. Zalmi. Faktor resiko yang berhubungan dengan kejadian Tuberkulosis paru di wilayah kerja Puskesmas Padang Pasir. Fakultas Kesehatan Masyarakat Universitas Indonesia. Universitas Indonesia. 2008

13. Machrita Hanum. Analisis Hubungan Perilaku Masyarakat dan Lingkungan Fisik Rumah terhadap Penularan Penyakit TBC di Puskesmas Tembelang Jombang Jawa Timur. 